no signs of intoxication were found (total medium molecular peptides content was reduced to 1.5 times, the content of TBA-active products and diene conjugates were also decreased), antioxidant processes (increase of glutathione content and activity of glutathione peroxidase while reducing the functional role of catalase) were activated (by increasing of succinate dehydrogenase and cytochrome oxidase activity, glutamate dehydrogenase - the way of glutamate formation), which contributed to the successful functioning of the antioxidant system and maintenance of energy and metabolic homeostasis in the body.

The obtained results enable the use of biologically active additives from chlorella, enriched with trace elements $\mathrm{Se}$ (IV), $\mathrm{Zn}$ (II) and Cr (III), as promising therapeutic and prophylactic substances, which will contribute to the successful functioning of the antioxidant system, maintain energy metabolism and metabolism correction of pathological processes, which is the basis for further studies of the biological activity of the complexes under study.

Key words: Chlorella vulgaris, trace elements (Selenium, Zinc, Chromium), rats, metabolism, regulation.

Надійшла 23.10.2020.

УДК 597.551.2:632.95

doi: $10.25128 / 2078-2357.20 .3-4.8$

О. І. БОДНАР, С. В. СЕНЬКО, І. О. ОСИПЕНКО, І. ХАТІБ, Н. М. КАСЯНЧУК, Г. І. ФАЛЬФУШИНСЬКА

Тернопільський національний педагогічний університет імені Володимира Гнатюка вул. М. Кривоноса, 2, Тернопіль, 46027

e-mail: falfushynska@tnpu.edu.ua

\title{
ВИВЧЕННЯ ЕФЕКТИВНОСТІ ХЛОРЕЛИ ЩОДО ЗМЕНШЕННЯ ЦИТОТОКСИЧНИХ ПРОЯВІВ У СМУГАСТОГО ДАНІО ЗА ВПЛИВУ ОРГАНОФОСФАТНИХ ПЕСТИЦИДІВ
}

Екологічний потенціал мікроводоростей щодо очищення водних і грунтових екосистем та відновлення їх гомеостатичного функціонального стану природним шляхом вважається одним з найвищих завдяки швидкому росту й розвитку, лабільному й динамічному їх метаболізму та відносній невибагливості до умов зростання. Метою нашої роботи було дослідити ефективність хлорели як потенційного біоремедіатора для зменшення токсичного впливу пестицидів раундапу та хлорпірифосу за умов їх індивідуальної та комплексної дії на коропову рибу даніо Danio rerio. Вплив екологічно реальних концентрацій раундапу (15 мкг/л) та хлорпірифосу $(0,1$ мкг/л) викликав часткове виснаження пулу клітинних тіолів порівняно 3 контролем, яке проявлялося зменшенням загального вмісту глутатіону та глутатіонтрансферазної активності (за умов поєднаного впливу). Також встановлене зменшення рівня загальної антиоксидантної активності, яке узгоджувалося зі збільшенням рівня активних форм оксигену в тканині печінки. Водночас у даніо не проявлялися гострі ознаки нейротоксичності - активність ацетилхолінестерази збільшувалася та тлі відсутності візуальних проявів порушення рухових реакцій. До специфічних, залежних від природи пестициду, реакцій можна віднести збільшення концентрації метилгліоксалю та найбільш помітні ознаки ендокринних розладів за вмістом вітелогеніну за дії хлорпірифосу. Інтегральний аналіз даних методом головних компонент дозволив виявити окрему локалізацію кожної з досліджуваних груп та проміжне положення тварин за умов комбінованого впливу порівняно з їх індивідуальною дією. Внесення Chlorella vulgaris у кількості близько 100 тис. кл/дм ${ }^{3}$ у середовище не продемонструвало істотного коригуючого впливу на токсичність пестицидів для нетаргетного організму Danio rerio, що не виключає позитивного впливу водоростей на функціонування екосистеми загалом та потребує більш детального аналізу. 
Ключові слова: Danio rerio, пестицици, токсичність, хлорела.

Пестициди та інші хімічні регулятори вегетаційних процесів є невід’ ємною часткою сучасної сільськогосподарської практики, що дозволяе збільшити врожайність і чистоту культур, зменшити супутні витрати та залучення людських ресурсів. Прогнозують, що до 2050 року населення Землі збільшиться до 10 мільярдів, що на 30 \% більше ніж у 2017 році. Збільшення чисельності популяції вимагає збільшення харчового ресурсу, що, згідно очікувань US Food and Agriculture Organization, на $80 \%$ буде забезпечуватися збільшенням площ аграрних угідь, а відтак і збільшенням використання хімічних засобів обробки агрокультур [35]. Станом на 2019 р. Україна займає 6 місце в світі за обсягом використання пестицидів [26]. У зв'язку із кумулятивними властивостями, тривалим періодом напіврозпаду (напр. для раундапу період піврозпаду становить 45-60 днів, для атразину - 200 днів (ATSDR, 2003)) більшість пестицидів циркулюють в екосистемах та можуть накопичуватися в нецільових організмах [34], викликаючи при цьому прояви ознак токсичності в живих організмів на різних рівнях еволюційного розвитку [5, 23]. Дослідження проведені за підтримки Агенції Охорони навколишнього середовища США продемонстрували наявність мікромолярних кількостей атразину та раундапу у близько $30 \%$ із 154 проаналізованих зразків річкової води [10].

Зважаючи на постійне збільшення обсягів використання пестицидів та їх фонового вмісту в поверхневих водах як компонента стоків із сільськогосподарських угідь, важливим $€$ питання їх біоремедіації з використанням доступних та екологічно безпечних засобів [1, 11, 14, 18]. До найбільш перспективних на часі відносять мікроводорості, які можуть знижувати рівень забруднення водного та грунтового середовища шляхом адсорбції, накопичення та метаболізму пестицидів до безпечних рівнів або перетворення їх у менш шкідливі або й нешкідливі сполуки і речовини $[1,29,32]$. Так, на прикладі одноклітинних зелених водоростей Chlamydomonas mexicana, Micractinium reisseri, Scenedesmus obliquus та Chlorella vulgaris показано, що за 14 діб залишкові концентрації атразину в середовищі в середньому знизилися від $18 \%$ до $40 \%$ за вмісту пестициду в середовищі 10 мкг/дм³ 25, 50 і 100 мкг/дм³ [16]. Разом 3 тим, існує небезпека негативного впливу мікроводоростей, насамперед ціанобактерій, на життєвий статус біоти, позаяк низка 3 них можуть продукувати токсичні метаболіти та викликати прояви токсичності [8].

Відтак, метою нашої роботи було дослідити ефективність хлорели як потенційного біоремедіатора для зменшення токсичного впливу широковикористовуваних пестицидів за умов їх індивідуальної та комплексної дії. Для дослідження ми обрали раундап та хлорпірифос відповідно до їх обсягів використання [6]. Як зручну біологічну модель для механістичних та токсикологічних досліджень нами була обрана коропова рибка даніо Danio rerio. Стан організму оцінювали за показниками стресу та токсичності, валідованими у попередніх наших дослідженнях $[8,13]$. Зокрема, антиоксидантно-прооксидантний баланс у клітині оцінювали за рівнем тіолів, загальної антиоксидантної активності та утворенням активних форм оксигену. Рівень цитотоксичності визначали за показниками ацетилхолінестерази (нейротоксичність) та вітелогенін-подібних протеїнів (ендокринні розлади). Визначали також активність фосфатази та рівень метилгліоксалю як побічного продукту гліколізу.

\section{Матеріал і методи досліджень}

Дослідження проводились на дорослих особинах даніо, родина Коропових, яких доставляли в лабораторію від комерційного об’єднання «Зоосвіт». Тварин аклімували до лабораторних умов протягом 7 діб. Експериментальні умови створювали в басейнах об'ємом 10 л з кількістю риб $з$ розрахунку 1 особина на 2 л води згідно загальноприйнятої схеми токсикологічного експерименту. Вміст кисню у воді підтримували на рівні 7,0-8,0 мг/л, вуглекислого газу - 2,22,8 мг/л, $\mathrm{pH}-7,6-8,0$. Воду відстоювали й змінювали через кожні дві доби, поновлюючи в експериментальних групах вміст досліджуваної сполуки у воді. Температура води становила $18 \pm 0,5^{\circ} \mathrm{C}$. Тварин годували подрібненим комерційним кормом Акваріус (Україна).

Було сформовано чотири групи тварин. Тварин контрольної групи утримували в присутності живих клітин хлорели $\left(\sim 100\right.$ тис. кл/дм $\left.{ }^{3}\right)[2,37,38]$. Трьом іншим групам паралельно з суспензією хлорели ( 100 тис. кл/дм³) у воду додавали раундап - 15 мкг/л (R), 
хлорпірифос - 0,1 мкг/л (CIP) та їх суміш у концентраціях 15 мкг/л та 0,1 мкг/л відповідно $(\mathrm{R}+\mathrm{ClP})$. Концентрації чинників відповідали діапазону їх концентрацій у поверхневих водах або місцях скиду побутових стоків $з$ полів [10]. Інкубація тварин тривала 14 діб.

Експерименти на тваринах проводили у відповідності до Європейської конвенції про захист хребетних тварин, яких використовують для експериментальних та наукових цілей (Страсбург, 1986), ухвали Першого національного конгресу з біоетики (Київ, 2000) та рішення етичної комісії Тернопільського національного педагогічного університету (Протокол № 2, 2020). Тварин умертвляли під етерним наркозом. Усі процедури з відбору і обробки тканини проводили на холоді. Усі реактиви були від фірми ТОВ «НВФ «Сінбіас» (Китай) і мали кваліфікацію «хч».

Методи визначення біомаркерів в тканинах даніо детально описані у статті [13]. Зокрема, вміст загального глутатіону у зразку тканини печінки визначали після повного відновлення глутатіону за допомогою глутатіонредуктази (Sigma, CWA) з використанням реактиву Елмана [3]. Реєстрували рівень 5-тіонітробензойної кислоти спектрофотометрично при 412 нм та виражали як мкмоль ТНБ/г тканини. Активність глутатіонтрансферази (GST) [КФ 2.5.1.18] визначали спектрофотометрично за утворенням адуктів 1-хлоро-2,4-динітробензену із глутатіоном з використанням мілімолярного коефіцієнту екстинкції забарвленого комплексу $\varepsilon_{340}=9.6 \mathrm{MM}^{-1}$ $\mathrm{cm}^{-1}$ [12]. Загальну антиоксидантну активність визначали з використанням ABTS (2, 2'-азинобіс-3-етилбензтіазолін-6-сульфонова кислота, Sigma) за методикою Shabestarian et al. [29]. Утворення активних форм оксигену в розчинній фазі гомогенату печінки в 20 мM HEPESсахарозному буфері $\mathrm{pH} 7,4$ оцінювали за утворенням флуоресцентного продукту родаміну 123 в реакції нефлуоресцентного деривату дигідрородаміну з активними формами кисню при хвилі збудження (ех.) $=485$ нм та випромінювання (em.) $=538$ нм [33].

Метилгліоксаль вимірювали в тканині печінки шляхом реакції 3 0,2 мМ 2,4динітрофенілгідразином [9] та визначали концентрацію 3 використанням молярного коефіцієнту екстинкції $3,36 \times 10^{4} \mathrm{M}^{-1} \mathrm{~cm}^{-1}$ при 432 нм і виражали у нмоль/г тканини. Маркер ендокринних розладів, концентрацію вітелогенін-подібних протеїнів, визначали як вміст лужнолабільних фосфатів за методом [4]. Вміст фосфату визначали колориметричним фосфомолібденовим методом.

Ацетилхолінестеразну активність [КФ 3.1.1.7] визначали колориметричним методом [7] у мозку даніо за здатністю гідролізувати ацетилтіохолін йодид (АТХ). Як індикатор тіолових груп використовували 5,5'-дитіо-біс-2-нітро-бензойну кислоту. Активність протеїн тирозинової фофатази визначали з використанням п-нітрофенолфосфату. Реєстрували рівень п-нітрофенолу спектрофотометрично при 405 нм [24].

Результати вимірів подані у вигляді $\mathrm{M} \pm \mathrm{SD}$ для 8 зразків тканини. Якщо дані згідно тесту Колмогорова-Смірнова не були нормально розподілені, їх трансформували 3 використанням методу Вох-Сох. Вірогідність ефекту групи та відмінності рядів параметричних даних обчислювали з використанням однофакторного дисперсійного аналізу ANOVA та LSD тесту. Вірогідною вважали відмінність між рядами за $p<0,05$. Аналіз біологічних параметрів здійснювали, використовуючи комп'ютерні програми Statistica v 12.0 та Exel для Windows-2016.

\section{Результати досліджень та їх обговорення}

Експозиція даніо у присутності екологічно реальних концентрацій раундапу та хлорпірифосу викликала загальне виснаження пулу клітинних тіолів за показниками глутатіонтрансферазної активності та, особливо, загального вмісту глутатіону (рис. 1). Зміни показників за умов комбінованого впливу були більш істотними, порівняно 3 їх індивідуальною дією. Рівень загальної антиоксидантної активності у більшості досліджуваних випадків також зменшувався узгоджено із збільшенням рівня активних форм оксигену у тканині печінки даніо $(\mathrm{r}=0,65$, $\mathrm{p}<0,05)$.

Вплив органофосфатних пестицидів викликає помітне пригнічення активності протеїн тирозинової фосфатази та активацію ацетилхолінестерази. Зміни рівня метилгліоксалю та вітелогеніну були пестицидо-специфічними (рис. 2). Зокрема, хлорпірифос викликав збільшення концентрації метилгліоксалю - активного дикарбонільного метаболіту, що утворюється як побічний продукт гліколізу [36]- та найбільш помітні ознаки ендокринних розладів за вмістом вітелогеніну. 64 ISSN 2078-2357. Наук. зап. Терноп. нац. пед. ун-ту. Сер. Біол., 2020, № 3-4 (80) 

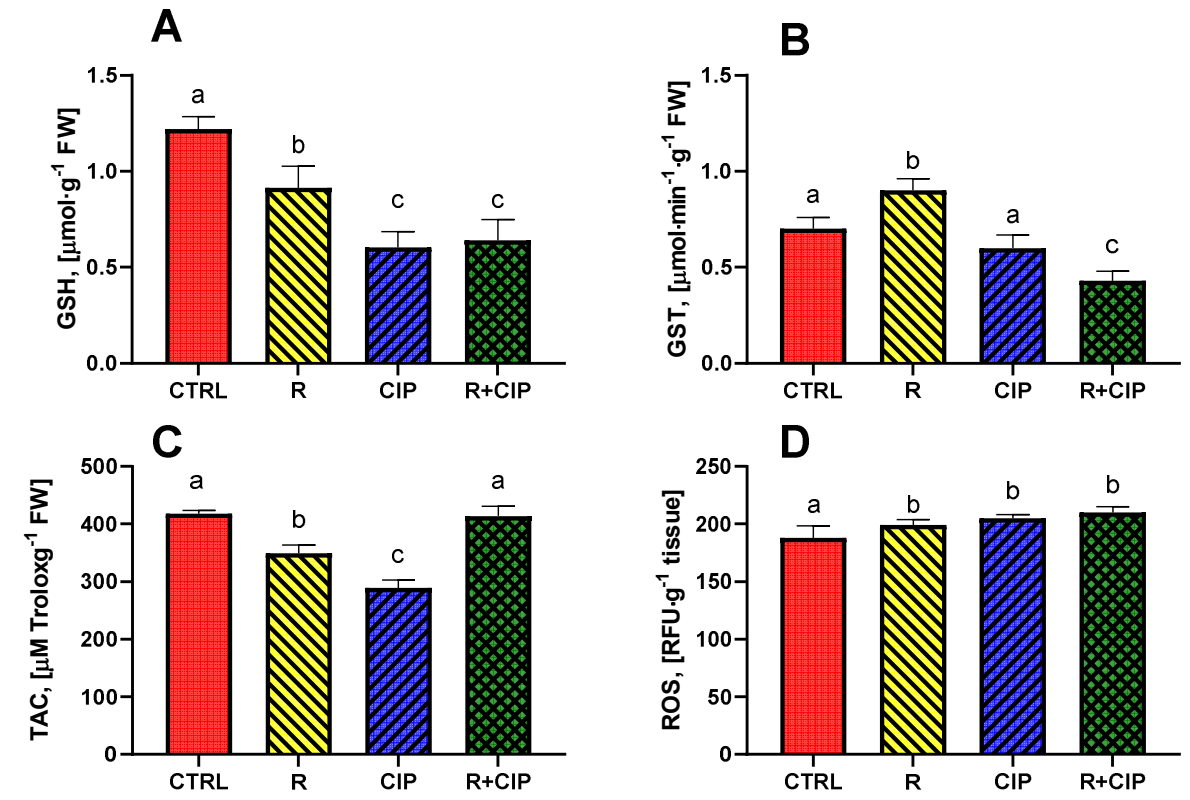

Рис. 1. Показники стану клітинних тіолів (А, В), загальної антиоксидантної активності (C) та утворення активних форм оксигену (D) у печінці даніо за дії раундапу (R), хлорпірифосу (ClP) та їх суміші (R+ClP) на організм протягом 14 діб.

A
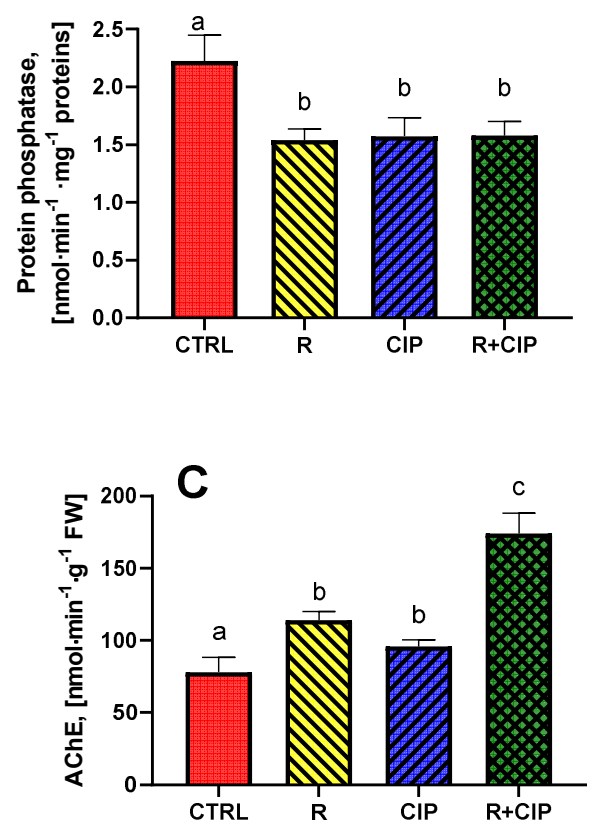

B
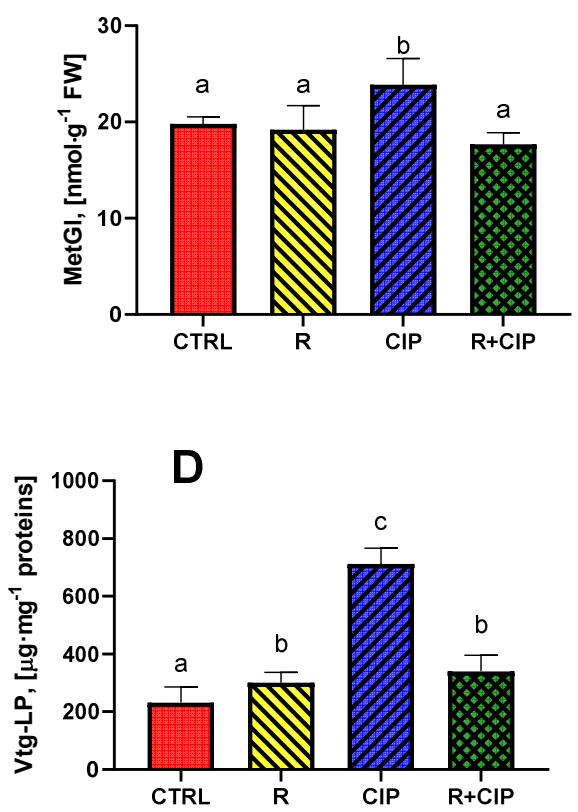

Рис. 2. Показники активності протеїн тирозинової фосфатазної (А), концентрації метилгліоксалю (В), ацетилхолінестеразної активності (С) та концентрації вітелогенін-подібних протеїнів (D) у печінці (A, B, D) та мозку (C) даніо за дії раундапу (R), хлорпірифосу (ClP) та їх суміші (R+ClP) на організм протягом 14 діб. 


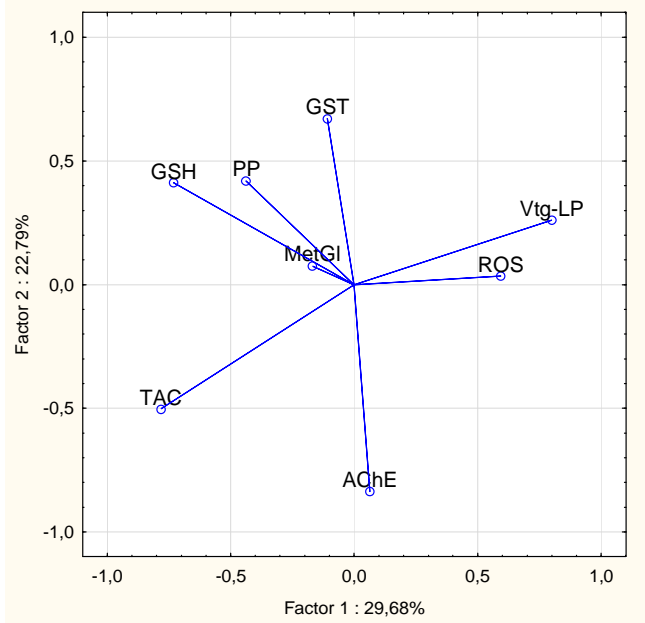

A

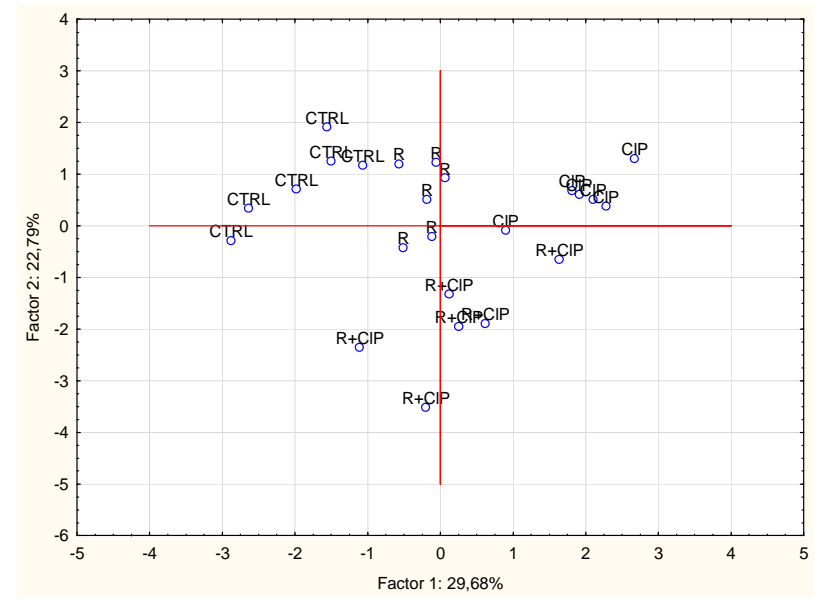

Б

Рис. 3. Інтегральний аналіз кореляційних зв’ язків між показниками окисного стресу та цитотоксичності у печінці та мозку смугастого даніо (А) та встановлення локалей дослідних груп (Б) методом головних компонент.

Використання методу головних компонент дозволило виявити кореляційні зв'язки між окремими досліджуваними параметрами окисного стресу та токсичності. Близько $52 \%$ абсолютних значень показників належать до Факторів 1 і 2 (рис. 3А). Глутатіон утворює спільний кластер 3 показником загальної антиоксидантної активності, який негативно пов'язаний із рівнем активних форм оксигену і вітелогеніну. Фактор 2, вірогідно, виділяє показники ацетилхолінестеразної та глутатіонтрансферазної активності. Кожна 3 досліджуваних груп займає окрему локаль (рис. 3Б), а тварини за умов комбінованого впливу проміжне положення між групами за умов індивідуальної дії.

Як було показано нами, за впливу всіх досліджуваних експериментальних чинників вміст ліпофосфоглікопротеїну вітелогеніну зростав, особливо за впливу хлорпірифосу. За нормальних умов вітелогенін виявляється у плазмі статевозрілих жіночих особин риб. Водночас, він може синтезуватися і в чоловічих особин за впливу екзогенних сполук, які викликають ураження ендокринної системи, зокрема синтетичних естрогенів, похідних алкіл фенолів, фітоестрогенів та деяких пестицидів, у зв'язку з чим його вважають специфічним маркером на дію ксеноестрогенів. Зокрема, вміст та експресія вітелогеніну зростає у плазмі крові самців карася за дії 4нонілфенолу [27], у печінці гамбузії Gambusia affinis за дії бісфенолу А та стоків зі сміттєзвалища [17] та у товстоголового губана за дії стоків аграрного виробництва [15]. Відтак, на основі наявності стійких ознак ендокринних розладів можна стверджувати про дію раундапу 
та хлорпірифосу в екологічно реальних концентраціях як ендокрин-дизрапторів, пошкоджувальна дія яких не коригується синхронною присутністю хлорели в середовищі.

Паралельно 3 ознаками ендокринних розладів у даніо проявляються ознаки нейротоксичності за збільшенням активності AXE та тлі відсутності візуальних проявів порушення рухових реакцій. У даному випадку ми не підтвердили загальноприйняту схему реакції АХЕ - пригнічення за дії сполук органофосфатної природи. Разом з тим, низка останніх досліджень свідчить про відносність поняття специфічності і для цього показника, особливо для коропових риб, оскільки АХЕ інгібується також алкалоїдами (сангвінарин, хелеритрин, берберин, бензофенантридин, морфін і диізохінолін), афлатоксином, природною сумішшю забруднювачів [25] та може проявляти неспецифічну реакцію - зростання активності ензиму в поєднанні з розладами локомоторної активності [21]. Наприклад, активацію АХЕ спостерігали в мозку коропа за дії 20,87 мкг/л біспирібак-соди в природних умовах на 7 добу експерименту [31], за дії екологічних концентрацій алюмінію (50 мкг/л) у смугастика Danio rerio, одночасно iз появою розладів локомоторної активності [28], у мозку даніо за дії 100 мкг/л токсину мікроцистину [20]. Відтак, специфічність та діапазон реакції ацетилхолінестерази мозку даніо за пливу органофосфатних пестицидів вимагає більш детального вивчення та з'ясування тонких механізмів регуляції.

За результатами інтегрального аналізу показники окисного стресу, а саме загальної антиоксидантної активності, глутатіону, GST та активних форм оксигену, в печінці даніо виділяються як чутливі до впливу екологічно реальних концентрацій органофосфатних пестицидів (рис. 3). Причому тварини реагують на дію пестицидів не активацією систем антиоксидантного захисту, а їх пригніченням, паралельно зі збільшенням рівня активних форм оксигену в клітині. Це, у свою чергу, може викликати окисне ушкодження біополімерів, у тому числі й ДНК, та ініціювати глибинні порушення на рівні спадкового апарату. Наші результати знаходять підтвердження і в літературі. Зокрема доведено, що у зябрах риби Oreochromis mossambicus за дії 30 мг/л профенофосу протягом 28 діб зменшується активність каталази, глутатіон-редуктази та вміст глутатіону, а також зростає COД, GST та рівень пероксидації ліпідів [19]. Подібні результати були отримані й за дії карбамазепіну в мозку Oncorhynchus mykiss, гексахлорбензолу в мозку коропа та тебуконазолу в печінці коропа, за виключенням тотального пригнічення СОД в концентраційно- та часозалежному аспекті [22].

Порівняння впливу органофосфатних пестицидів за умов їх індивідуальної та комбінованої дії не виявило істотних ознак адитивного ефекту, за винятком пригнічення GST, яка, одночасно із залученням до антиоксидантного захисту, включається в біотрансформацію ксенобіотиків, зокрема каталізує реакцію кон'югації електрофільних субстанцій з глутатіоном. За індивідуальної дії раундапу (гліфосату), який метаболізує до гліоксилату, що має електрофільні властивості, ми спостерігаємо активацію біотрансформаційних процесів за збільшенням GST та частковим вилученням глутатіону з пулу клітинних тіолів. Разом 3 тим, присутність хлорпірифосу, як індивідуально, так і особливо в суміші, порушує детоксикаційні механізми знешкодження електрофільних субстанцій. Інгібуючий ефект хлорпірифосу на II фазу детоксикації ксенобіотиків був також доведений і на щурах [30]. Більше того, протеїнова фосфатаза, яка також може залучатися до гідролізу органофосфатів у мікроорганізмів та ссавців [30], теж не була задіяна в метаболічні процеси.

\section{Висновки}

Отже, дія екологічно реальних концентрацій органофосфатних пестицидів раундапу та хлорпірифосу, як окремо, так і в суміші, викликає в смугастого даніо пригнічення систем антиоксидантного захисту, узгоджену зі збільшенням рівня активних форм оксигену, появу ознак ендокринних розладів та активацію гліколізу (як специфічна ознака впливу хлорпірифосу). Разом 3 тим, гострих ознак нейротоксичності в даніо виявлено не було. Внесення Chlorella vulgaris у кількості близько 100 тис. кл/дм ${ }^{3}$ у середовище не продемонструвало істотного коригуючого впливу на токсичність пестицидів для Danio rerio, що не виключає позитивного впливу водоростей на функціонування екосистеми загалом, та потребує подальших комплексних досліджень. Таким чином, потрапляння в поверхневі води стоків 3 сільськогосподарських угідь, що містять навіть фонові концентрації органофосфатних ISSN 2078-2357. Наук. зап. Терноп. нац. пед. ун-ту. Сер. Біол., 2020, № 3-4 (80) 
пестицидів, може становити небезпеку для нецільових організмів, а використання водоростей у процесах детоксикації потребує більш детального гідробіологічного аналізу.

\section{Подяка}

Робота виконана за підтримки Національного фонду досліджень України (№ 2020.02/0270) та Міністерства освіти і науки (№ MB-2).

1. Abdel-Razek M. A., Abozeid A. M., Eltholth M. M., Abouelenien F. A., El-Midany S. A., Moustafa N. Y., Mohamed R. A. Bioremediation of a pesticide and selected heavy metals in wastewater from various sources using a consortium of microalgae and cyanobacteria. Slovenian Veterinary Research. 2019. Vol. 56, Is. 22. P. 61-74. doi: 10.26873/SVR-744-2019

2. Algae of Ukraine: diversity, nomenclature, taxonomy, ecology and geography. Vol. 3. Chlorophyta. / P. M. Tsarenko, S. P. Wasser, E. Nevo. Ruggell: Ganter Verlag, 2011. 511 p.

3. Anderson M. E. Determination of glutathione and glutathione disulfide in biological samples. Methods Enzymol. 1985. Vol. 113. P. 548-555.

4. Blaise C., Gagne F., Pellerin J., Hansen D. Determination of vitellogenin-like properties in Mya arenaria hemolymph (Saguenay Fjord, Canada): A potential biomarker for endocrine disruption. Environ Toxicol. 1999. Vol. 14. P. 455-465.

5. Carvalho F. P. Pesticides, environment, and food safety. Food and Energy Security. 2017. Vol. 6, Is. 2. P. 48-60. doi: 10.1002/fes3.108

6. Dosnon-Olette R., Trotel-Aziz P., Couderchet M., Eullaffroy P. Fungicides and herbicide removal in Scenedesmus cell suspensions. Chemosphere. 2010. Vol.79, Is. 2. P. 117-123. https://doi.org/10.1016/j.envpol.2005.12.014

7. Ellman G. I., Courtney K. D., Andres Jr. V., Featherstone R. M. A new and rapid colorimetric determination of acetylcholinesterase activity. Biochem. Pharmacol. 1961. Vol. 7. P. 88-95. doi: 10.1016/0006-2952(61)90145-9

8. Falfushynska H. I., Horyn O. I., Fedoruk O. O., Buyak B., et al. Is the presence of Central European strains of Raphidiopsis (Cylindrospermopsis) raciborskii a threat to a freshwater fish? An in vitro toxicological study in common carp cells. Aquatic Toxicology. 2019. Vol. 206. P. 105-113. doi: 10.1016/j.aquatox.2018.11.012

9. Falfushynska H. I., Horyn O. I., Gnatyshyna L. L., Buyak B. B., Rusnak N. I., Fedoruk O. O., Stoliar O. B. Carassius auratus as a novel model for the hyperglycemia study. Ukr. Biochem. J. 2019. Vol. 91, Is. 4. P. 58-69. DOI: 10.15407/ubj91.04.058

10. Glyphosate herbicide found in many midwestern streams, antibiotics not common [Electronic resource] URL: https://toxics.usgs.gov/highlights/glyphosate02.html (дата звернення 10.11.2020).

11. Gonzalez-Barreiro O., Rioboo C., Herrero C., Cid A. Removal of triazine herbicides from freshwater systems using photosynthetic microorganisms. Environmental Pollution. 2006. Vol. 44, Is.1. P. 266-271. https://doi.org/10.1016/j.envpol.2005.12.014

12. Habig W. H., Pabst M. J., Jakoby W. B. Glutathione S-transferases. The first enzymatic step in mercapturic acid formation. J. Biol. Chem. 1974. Vol. 249, Is. 22. P. 7130-7139.

13. Henao E., Murphy P. J., Falfushynska H., Horyn O., Evans D. M., Klimaszyk P., Rzymski P. Polymethoxy1-alkenes screening of Chlorella and Spirulina food supplements coupled with in vivo toxicity studies. Toxins. 2020. Vol. 12, Is. 2. P. 111. doi: 10.3390/toxins 12020111

14. Hultberg M., Bodin H. Effects of fungal-assisted algal harvesting through biopellet formation on pesticides in water. Biodegradation. 2018. Vol. 29. P. 557-565. https://doi.org/10.1007/s10532-018-9852-y

15. Jeffries S. K., Abbott K. I., Cowman T., Kolok A. S. Occurrence and endocrine effects of agrichemicals in a small Nebraska, USA, watershed. Environ. Toxicol. Chem. 2011. Vol. 30, Is. 10. P. 2253-2260.

16. Kabra N. A., Ji M.-K., Choi J., Kim R. J., Govindwar S. P., Jeon B. H. Toxicity of atrazine and its bioaccumulation and biodegradation in a green microalga, Chlamydomonas mexicana. Environ. Sci. Pollut. Res. 2014. Vol. 21. P. 12270-12278. https://doi.org/10.1007/s11356-014-3157-4

17. Kamata R., Itoh K., Nakajima D., Itoh K., Nakajima D., Kageyama S., Sawabe A., Terasaki M., Shiraishi F. The feasibility of using mosquitofish (Gambusia affinis) for detecting endocrine-disrupting chemicals in the freshwater environment. Environ. Toxicol. Chem. 2011. Vol. 30, Is. 12. P. $2778-2785$.

18. Karthikeyan R., Davis L. C., Erickson L. E., Al-Khatib K., Kulakow P., Barnes P. L., Hutchinson S. L., Nurzhanova A. A. Potential for plant-based remediation of pesticide-contaminated soil and water using nontarget plants such as trees, shrubs, and grasses. Critical reviews in Plant Sciences. 2004. Vol. 23, Is. 1. P. 91-101. doi: 10.1080/07352680490273518 
19. Kavitha P., Rao J. V. Sub-lethal effects of profenofos on tissue-specific antioxidative responses in a Euryhyaline fish, Oreochromis mossambicus. Ecotoxicol. Environ. Saf. 2009. Vol. 72, Is. 6. P. 1727-1733.

20. Kist L. W., Rosemberg D. B., Pereira T. C., et al. Microcystin-LR acute exposure increases AChE activity via transcriptional ache activation in zebrafish (Danio rerio) brain. Comp. Biochem. Physiol. 2012. Vol. 155C, Is. 2. P. 247-252. https://doi.org/10.1016/j.cbpc.2011.09.002

21. Kopecka-Pilarczyk J., Correia A. D. Biochemical response in gilthead seabream (Sparus aurata) to in vivo exposure to a mix of selected PAHs. Ecotoxicol. Environ. Saf. 2009. Vol. 72. P. 1296-1302. doi: 10.1016/j.aquatox.2018.11.012

22. Li Z. H., Zlabek V., Velisek J. R., Grabic R., Machova J., Randak T. Modulation of antioxidant defence system in brain of rainbow trout (Oncorhynchus mykiss) after chronic carbamazepine treatment. Comp. Biochem. Physiol. 2010. Vol. 151C, Is. 1. P. 137-141. doi: 10.1016/j.cbpc.2009.09.006

23. Lushchak V. I., Matviishyn T. M., Husak V. V. Pesticide toxicity: a mechanistic approach. EXCLI J. 2008. Vol. 17. P. 1101-1136. doi: 10.17179/excli2018-1710

24. McAvoy T., Nairn A. C. Serine/threonine protein phosphatase assays. Protoc. Mol. Biol. 2010. Vol. 18. P. 8. doi:10.1002/0471142727.mb1818s92

25. Moscone D., Arduini F., Amine A. A rapid enzymatic method for aflatoxin B detection. Methods Mol. Biol. 2011. Vol. 739. P. 217-235.

26. Pesticide use by country [Electronic resource] / link: https://www.worldometers.info/foodagriculture/pesticides-by-country/ (дата звернення: 10.11.2020).

27. Pomatto V., Palermo F., Mosconi G., et al. Xenoestrogens elicit a modulation of endocannabinoid system and estrogen receptors in 4NP treated goldfish, Carassius auratus. Gen. Comp. Endocrinol. 2011. Vol. 174, Is. 1. P. 30-35.

28. Senger M. R., Seibt K. J., Ghisleni G. C., Dias R. D., Bogo M. R., Bonan C. D. Aluminum exposure alters behavioral parameters and increases acetylcholinesterase activity in zebrafish (Danio rerio) brain. Cell. Biol. Toxicol. 2011. Vol. 27, Is. 3. P. 199-205.

29. Shabestarian H., Homayouni-Tabrizi M., Soltani M., Namvar F., Azizi S., Mohamad R. Green synthesis of gold nanoparticles using sumac aqueous extract and their antioxidant activity. Materials Research. 2017. Vol. 20, Is. 1. P. 264-270. doi: 10.1590/1980-5373-MR-2015-0694

30. Sharma S., Singh P., Chadha P., Saini H. S. Toxicity assessment of chlorpyrifos on different organs of rat: exploitation of microbial-based enzymatic system for neutralization. Environ. Sci. Pollut. Res. 2019. Vol. 26. P. 29649-29659. https://doi.org/10.1007/s11356-019-06140-8

31. Toni C., Menezes C. C., Loro V. L., Clasen B. E., Cattaneo R., Santi A., Pretto A., Zanella R., Leitemperger J. Oxidative stress biomarkers in Cyprinus carpio exposed to commercial herbicide bispyribac-sodium. J. Appl. Toxicol. 2010. Vol. 30, Is. 6. P. 590-595.

32. Uqab B., Mudasir S., Nazir R. Review on bioremediation of pesticides. J. Bioremed. Biodeg. 2016. Vol. 7 , № 3. P. 343-348. doi:10.4172/2155-6199.1000343.

33. Viarengo A., Burlando B., Cavaletto M., Marchi B., Ponzano E., Blasco J. Role of metallothionein against oxidative stress in the mussel Mytilus galloprovincialis. Am. J. Physiol. 1999. Vol. 277, Is. 6 Pt 2. P. R1612-9. DOI: 10.1152/ajpregu.1999.277.6.R1612

34. Wilkinson C. F., Christoph G. R., Julien E., Kelley J. M., Kronenberg J., McCarthye J., Reissa R. Assessing the risks of exposures to multiple chemicals with a common mechanism of toxicity: how to cumulate? Regul. Toxicol. Pharmacol. 2000. Vol. 31. P. 30-43.

35. World Health Organization [Electronic resource] / link: https://www.who.int/

36. Горин О. I., Фальфушинська Г. I. Екстракт момордіки пригнічує окисний стрес та збільшує гемолітичну стійкість еритроцитів коропа за впливу глюкози. Наук. зап. Терноп. нац. пед. ун-ту. Сер. Біол. 2019. № 1, Т. 75. С. 21-28. https://doi.org/10.25128/2078-2357.19.1.3

37. Кравцова О.В. Фітопланктон різнотипних водойм природоохоронних і урбанізованих територій : автореферат дис. на здобуття наук. ступеня канд. біол. наук : 03.00.17. Київ, 2019. 20 с.

38. Малахов Ю. П. Новые данные о разнообразии водорослей Ривненского природного заповедника. Альгология. 2014. Т.24, № 3. С. 399-340.

\section{References}

1. Abdel-Razek M. A., Abozeid A. M., Eltholth M. M., Abouelenien F. A., El-Midany S. A., Moustafa N. Y., Mohamed R. A. Bioremediation of a pesticide and selected heavy metals in wastewater from various sources using a consortium of microalgae and cyanobacteria. Slovenian Veterinary Research. 2019. Vol. 56, Is. 22. P. 61-74. doi: 10.26873/SVR-744-2019

2. Algae of Ukraine: diversity, nomenclature, taxonomy, ecology and geography. Vol. 3. Chlorophyta. / P. M. Tsarenko, S. P. Wasser, E. Nevo. Ruggell: Ganter Verlag, 2011. 511 p.

ISSN 2078-2357. Наук. зап. Терноп. нац. пед. ун-ту. Сер. Біол., 2020, № 3-4 (80) 
3. Anderson M. E. Determination of glutathione and glutathione disulfide in biological samples. Methods Enzymol. 1985. Vol. 113. P. 548-555.

4. Blaise C., Gagne F., Pellerin J., Hansen D. Determination of vitellogenin-like properties in Mya arenaria hemolymph (Saguenay Fjord, Canada): A potential biomarker for endocrine disruption. Environ Toxicol. 1999. Vol. 14. P. 455-465.

5. Carvalho F. P. Pesticides, environment, and food safety. Food and Energy Security. 2017. Vol. 6, Is. 2. P. 48-60. doi: 10.1002/fes3.108

6. Dosnon-Olette R., Trotel-Aziz P., Couderchet M., Eullaffroy P. Fungicides and herbicide removal in Scenedesmus cell suspensions. Chemosphere. 2010. Vol. 79, Is. 2. P. 117-123. https://doi.org/10.1016/j.envpol.2005.12.014

7. Ellman G. I., Courtney K. D., Andres Jr. V., Featherstone R. M. A new and rapid colorimetric determination of acetylcholinesterase activity. Biochem. Pharmacol. 1961. Vol. 7. P. 88-95. doi: 10.1016/0006-2952(61)90145-9

8. Falfushynska H. I., Horyn O. I., Fedoruk O. O., Buyak B., et al. Is the presence of Central European strains of Raphidiopsis (Cylindrospermopsis) raciborskii a threat to a freshwater fish? An in vitro toxicological study in common carp cells. Aquatic Toxicology. 2019. Vol. 206. P. 105-113. doi: 10.1016/j.aquatox.2018.11.012

9. Falfushynska H. I., Horyn O. I., Gnatyshyna L. L., Buyak B. B., Rusnak N. I., Fedoruk O. O., Stoliar O. B. Carassius auratus as a novel model for the hyperglycemia study. Ukr. Biochem. J. 2019. Vol. 91, Is. 4. P. 58-69. DOI: 10.15407/ubj91.04.058

10. Glyphosate herbicide found in many midwestern streams, antibiotics not common [Electronic resource] URL: https://toxics.usgs.gov/highlights/glyphosate02.html (дата звернення 10.11.2020).

11. Gonzalez-Barreiro O., Rioboo C., Herrero C., Cid A. Removal of triazine herbicides from freshwater systems using photosynthetic microorganisms. Environmental Pollution. 2006. Vol. 44, Is.1. P. $266-271$. https://doi.org/10.1016/j.envpol.2005.12.014

12. Habig W. H., Pabst M. J., Jakoby W. B. Glutathione S-transferases. The first enzymatic step in mercapturic acid formation. J. Biol. Chem. 1974. Vol. 249, Is. 22. P. 7130-7139.

13. Henao E., Murphy P. J., Falfushynska H., Horyn O., Evans D. M., Klimaszyk P., Rzymski P. Polymethoxy1-alkenes screening of Chlorella and Spirulina food supplements coupled with in vivo toxicity studies. Toxins. 2020. Vol. 12, Is. 2. P. 111. doi: 10.3390/toxins 12020111

14. Hultberg M., Bodin H. Effects of fungal-assisted algal harvesting through biopellet formation on pesticides in water. Biodegradation. 2018. Vol. 29. P. 557-565. https://doi.org/10.1007/s10532-018-9852-y

15. Jeffries S. K., Abbott K. I., Cowman T., Kolok A. S. Occurrence and endocrine effects of agrichemicals in a small Nebraska, USA, watershed. Environ. Toxicol. Chem. 2011. Vol. 30, Is. 10. P. 2253-2260.

16. Kabra N. A., Ji M.-K., Choi J., Kim R. J., Govindwar S. P., Jeon B. H. Toxicity of atrazine and its bioaccumulation and biodegradation in a green microalga, Chlamydomonas mexicana. Environ. Sci. Pollut. Res. 2014. Vol. 21. P. 12270-12278. https://doi.org/10.1007/s11356-014-3157-4

17. Kamata R., Itoh K., Nakajima D., Itoh K., Nakajima D., Kageyama S., Sawabe A., Terasaki M., Shiraishi F. The feasibility of using mosquitofish (Gambusia affinis) for detecting endocrine-disrupting chemicals in the freshwater environment. Environ. Toxicol. Chem. 2011. Vol. 30, Is. 12. P. 2778 -2785.

18. Karthikeyan R., Davis L. C., Erickson L. E., Al-Khatib K., Kulakow P., Barnes P. L., Hutchinson S. L., Nurzhanova A. A. Potential for plant-based remediation of pesticide-contaminated soil and water using nontarget plants such as trees, shrubs, and grasses. Critical reviews in Plant Sciences. 2004. Vol. 23, Is. 1. P. 91-101. doi: 10.1080/07352680490273518

19. Kavitha P., Rao J. V. Sub-lethal effects of profenofos on tissue-specific antioxidative responses in a Euryhyaline fish, Oreochromis mossambicus. Ecotoxicol. Environ. Saf. 2009. Vol. 72, Is. 6. P. 1727-1733.

20. Kist L. W., Rosemberg D. B., Pereira T. C., et al. Microcystin-LR acute exposure increases AChE activity via transcriptional ache activation in zebrafish (Danio rerio) brain. Comp. Biochem. Physiol. 2012. Vol. 155C, Is. 2. P. 247-252. https://doi.org/10.1016/j.cbpc.2011.09.002

21. Kopecka-Pilarczyk J., Correia A. D. Biochemical response in gilthead seabream (Sparus aurata) to in vivo exposure to a mix of selected PAHs. Ecotoxicol. Environ. Saf. 2009. Vol. 72. P. 1296-1302. doi: 10.1016/j.aquatox.2018.11.012

22. Li Z. H., Zlabek V., Velisek J. R., Grabic R., Machova J., Randak T. Modulation of antioxidant defence system in brain of rainbow trout (Oncorhynchus mykiss) after chronic carbamazepine treatment. Comp. Biochem. Physiol. 2010. Vol. 151C, Is. 1. P. 137-141. doi: 10.1016/j.cbpc.2009.09.006

23. Lushchak V. I., Matviishyn T. M., Husak V. V. Pesticide toxicity: a mechanistic approach. EXCLI J. 2008. Vol. 17. P. 1101-1136. doi: 10.17179/excli2018-1710

24. McAvoy T., Nairn A. C. Serine/threonine protein phosphatase assays. Protoc. Mol. Biol. 2010. Vol. 18. P. 8. doi:10.1002/0471142727.mb1818s92

70 ISSN 2078-2357. Наук. зап. Терноп. нац. пед. ун-ту. Сер. Біол., 2020, № 3-4 (80) 
25. Moscone D., Arduini F., Amine A. A rapid enzymatic method for aflatoxin B detection. Methods Mol. Biol. 2011. Vol. 739. P. 217-235.

26. Pesticide use by country [Electronic resource] / link: https://www.worldometers.info/foodagriculture/pesticides-by-country/ (дата звернення: 10.11.2020).

27. Pomatto V., Palermo F., Mosconi G., et al. Xenoestrogens elicit a modulation of endocannabinoid system and estrogen receptors in 4NP treated goldfish, Carassius auratus. Gen. Comp. Endocrinol. 2011. Vol. 174, Is. 1. P. 30-35.

28. Senger M. R., Seibt K. J., Ghisleni G. C., Dias R. D., Bogo M. R., Bonan C. D. Aluminum exposure alters behavioral parameters and increases acetylcholinesterase activity in zebrafish (Danio rerio) brain. Cell. Biol. Toxicol. 2011. Vol. 27, Is. 3. P. 199-205.

29. Shabestarian H., Homayouni-Tabrizi M., Soltani M., Namvar F., Azizi S., Mohamad R. Green synthesis of gold nanoparticles using sumac aqueous extract and their antioxidant activity. Materials Research. 2017. Vol. 20, Is. 1. P. 264-270. doi: 10.1590/1980-5373-MR-2015-0694

30. Sharma S., Singh P., Chadha P., Saini H. S. Toxicity assessment of chlorpyrifos on different organs of rat: exploitation of microbial-based enzymatic system for neutralization. Environ. Sci. Pollut. Res. 2019. Vol. 26. P. 29649-29659. https://doi.org/10.1007/s11356-019-06140-8

31. Toni C., Menezes C. C., Loro V. L., Clasen B. E., Cattaneo R., Santi A., Pretto A., Zanella R., Leitemperger J. Oxidative stress biomarkers in Cyprinus carpio exposed to commercial herbicide bispyribac-sodium. J. Appl. Toxicol. 2010. Vol. 30, Is. 6. P. 590-595.

32. Uqab B., Mudasir S., Nazir R. Review on bioremediation of pesticides. J. Bioremed. Biodeg. 2016. Vol. 7 , № 3. P. 343-348. doi:10.4172/2155-6199.1000343.

33. Viarengo A., Burlando B., Cavaletto M., Marchi B., Ponzano E., Blasco J. Role of metallothionein against oxidative stress in the mussel Mytilus galloprovincialis. Am. J. Physiol. 1999. Vol. 277, Is. 6 Pt 2. P. R1612-9. DOI: 10.1152/ajpregu.1999.277.6.R1612

34. Wilkinson C. F., Christoph G. R., Julien E., Kelley J. M., Kronenberg J., McCarthye J., Reissa R. Assessing the risks of exposures to multiple chemicals with a common mechanism of toxicity: how to cumulate? Regul. Toxicol. Pharmacol. 2000. Vol. 31. P. 30-43.

35. World Health Organization [Electronic resource] / link: https://www.who.int/

36. Horyn O. I., Falfushynska H. I. Ekstrakt momordiky pryhnichuie okysnyi stres ta zbilshuie hemolitychnu stiikist erytrotsytiv koropa za vplyvu hliukozy. Nauk. zap. Ternop. nats. ped. un-tu. Ser. Biol. 2019. № 1, T. 75. S. 21-28. [in Ukrainian]

37. Kravtsova O. V. Fitoplankton riznotypnykh vodoim pryrodookhoronnykh i urbanizovanykh terytorii : avtoreferat dys. na zdobuttia nauk. stupenia kand. biol. nauk : 03.00.17. Kyiv, 2019. 20 s. [in Ukrainian]

38. Malakhov Yu. P. Novye dannye o raznoobrazyy vodoroslei Ryvnenskoho pryrodnoho zapovednyka. Alholohyia. 2014. T.24, № 3. S. 399-40. [in Russian]

O. I. Bodnar, S. V. Senko, I. O. Osypenko, I. Khatib, N. M. Kasyanchuk, H. I. Falfushynska

Ternopil Volodymyr Hnatiuk National Pedagogical University, Ukraine

STUDY OF THE EFFECTIVENESS OF CHLORELLA AGAINST ATTENUATION OF CYTOXIC SIGNS IN ZEBRAFISH EXPOSED TO ORGANOPHOSPHATE PESTICIDES

The ecological potential of microalgae for purification of aquatic and soil ecosystems and natural restoration of their homeostatic functional state is considered to be high due to the rapid growth and development of algae, their labile and dynamic metabolism and simple growth conditions. The aim of present work was to study the effectiveness of Chlorella as a potential bioremediator to reduce the toxic effects of pesticides, roundup and chlorpyrifos after their individual and complex influence on zebrafish Danio rerio. The effect of environmental concentrations of roundup $\left(15 \mu \mathrm{g} \oplus \mathrm{L}^{-1}\right)$ and chlorpyrifos $\left(0,1 \mu \mathrm{g} \oplus \mathrm{L}^{-1}\right)$ provoked partial depletion of the cell thiols pool when compared to the control, which appeared as a decrease in glutathione transferase activity (under combined exposure) and total glutathione concentration. A decrease in the level of total antioxidant capacity, which was consistent with an increase in the level of reactive oxygen species in the liver tissue was also shown. Meanwhile, the studied organophosphate pesticides didn't cause severe signs of neurotoxicity, but activated acetylcholinesterase in line with no visual manifestations of locomotion reactions. Chlorpyrifos determined an increase in the concentration of methylglyoxal and the most noticeable sign of endocrine disruption from all studied groups in terms of vitellogenin concentration. Principal component analysis allowed to identify a separate localization of each of the studied groups and the interim position of animals after combined exposure when compared to the individual action. The 
introduction of Chlorella vulgaris in the exposure media in the amount of about 100 thousand cells / $\mathrm{dm}^{3}$ did not show a significant corrective effect on the toxicity of pesticides for non-target species Danio rerio, which doesn't exclude the positive impact of algae on the functioning of the ecosystem in general and requires a more detailed analysis.

Key words: Danio rerio, pesticides, toxicity, chlorella.

Надійшла 24.11.2020.

UDC 557.352.38:577.64

doi: $10.25128 / 2078-2357.20 .3-4.9$

${ }^{1} \mathrm{~V}$. KHOMA, ${ }^{1,2} \mathrm{~L}$. GNATYSHYNA, ${ }^{1} \mathrm{~V}$. MARTINYUK, ${ }^{1,2} \mathrm{~T}$. MACKIV, ${ }^{1} \mathrm{~K}$. YUNKO,

${ }^{1}$ R. FORMANCHUK, ${ }^{1}$ V. BARANOVSKII, ${ }^{1} \mathrm{M}$. GLADYUK, ${ }^{3}$ L. MANUSADŽIANAS, ${ }^{1}$ O. STOLIAR ${ }^{*}$

${ }^{1}$ Ternopil Volodymyr Hnatiuk National Pedagogical University

Kryvonosa Str 2, Ternopil, Ukraine, 46027

${ }^{2}$ I. Horbachevsky Ternopil National Medical University, Ternopil, Ukraine

${ }^{3}$ Nature Research Centre, Vilnius, Lithuania

e-mail: Oksana.Stolyar@tnpu.edu.ua

\section{COMBINE EXPOSURES TO LOW ROUNDUPCONCENTRATION INDUCES THIOLOME RESPONSE IN THE DIGESTIVE GLAND OF BIVALVE MOLLUSK}

Glyphosate is one of most popular weed killers in the word. Its toxicity to aquatic organisms was investigated mostly in the acute high experimental exposures. The aim of this study was to evaluate the effect of low, 0.5 of Predicted No Effect Concentration (PNEC), of glyphosate in the combinations to freshwater bivalve mollusks. We treated the mussels Unio tumidus with glyphosatebased herbicide RoundupMAX (Rn, correspondent to $16.9 \mu \mathrm{g} \mathrm{L}^{-1}$ or $40 \mathrm{nM}$ of glyphosate) in the combination with heating $25^{\circ} \mathrm{C}(\mathrm{RnT})$ or chlorpromazine (RnCpz, $18.0 \mu \mathrm{g} \mathrm{L}^{-1}$ or $56 \mathrm{nM}$ of $\mathrm{Cpz}$ ) and $\mathrm{Cpz}$ alone during 14 days. The responses of oxidative stress were evaluated in the digestive gland. The enzyme activities were changed only by the exposures to Rn (increase of superoxide dismutase) and $\mathrm{Cpz}$ (decrease of catalase), whereas the elevation of total glutathione (GSH) level was indicated in all exposures except $\mathrm{Rn}$, and metallothonein-associated thiols (MTSH) - in all exposures except Cpz. Lipid peroxidation was increased in all exposures by $16.6 \%$ maximally. Total balance of antioxidants versus prooxidative changes was increased in all exposures contained $\mathrm{Rn}$ (by $\sim 3$ times in RnT-group) and decreased in the exposure to $\mathrm{Cpz}$ alone. Metallothionein chromatographyc features did not indicate substantial oxidative changes in all exposed groups. Hence, combine exposures distort prominently the oxidative stress responses to xenobiotics in the freshwater mussels even in low, nanomolar concentrations. The ability of Rn to induce MTSH seems to be the decisive input in the antioxidant defence at combine exposures.

Key words: Bivalve mollusk, Roundup, Heating, Chlorpromazine, Antioxidants, Metallothioneins, Thiolome.

Formulation Roundup (commercial form of phosphonoorganic glyphosate) belongs to most utilised pesticides over the world as weed killer [15]. Glyphosate has not molecular targets in the animals, but it inhibits the enzyme 5-enolpyruvylshikimate 3-phosphate (EPSP) synthase (EC 2.5.1.19) of the shikimate pathway, which is essential for the synthesis of aromatic amino acids and of almost all other aromatic compounds in algae, higher plants, bacteria, and fungi [20]. However, its utilization since 1974 had brought several negative experiences concerning its impact on the non-targeted organisms. Both its active ingredient glyphosate and the adjuvants presented in the commercial formulations were 